\title{
Analysis on the Opinions of Employees Working in Provincial Directorates of Youth and Sports Regarding Six Sigma Management Model
}

\author{
Ali Serdar Yücel*, Özgür Karataş \\ Department of Sport Management, Faculty of Sports Sciences, Frrat University, Turkey
}

Copyright $(2019$ by authors, all rights reserved. Authors agree that this article remains permanently open access under the terms of the Creative Commons Attribution License 4.0 International License

\begin{abstract}
The purpose of this study is to evaluate the opinions of those working in Provincial Directorates of Youth and Sports - serving as the field service within the body of General Directorate of Sports affiliated to the Ministry of Youth and Sports in Turkey - regarding the applicability of Six Sigma management model by some variables. "Descriptive Survey Model" was used in this research. The research population is composed of the employees working in Provincial Directorates of Youth and Sports in Turkey and the sample is composed of randomly selected 210 employees among those actively working in these directorates. A questionnaire was applied in obtaining the research data. It has been determined in the research that the opinions of the participants on the applicability of Six Sigma management model are positive, a quality management model isn't applied in provincial directorates, quality education isn't addressed sufficiently and there isn't any quality department or the personnel recruited in this department. In conclusion, it has been established that employee opinions on the applicability of Six Sigma management model in Provincial Directorates of Youth and Sports are positive and they constitute a basis for the applicability of Six Sigma management model when the research results are addressed by taking into account the fact that ensuring the leadership and support of top management in addition to the principles of Six sigma management model, such as Customer orientation, Tolerance for failure, Process-oriented Management and Continuous Development. Active Participation of Everyone and Tolerance for Failure are two of the highly important steps of "Six Sigma" applications.
\end{abstract}

Keywords Sports, Youth, Six Sigma, Product, Quality

\section{Introduction}

Quality shows itself as an important concept in every sector such as education, banking, hotel and automotive. Process variables need to be minimized to ensure continuity of quality. Six sigma is a model that minimizes process variables, provides financial improvement and mainly focuses on the process improvement efforts as the basic topic [10].

One of the sectors affected by rapid change and development in the world is sports. The diversification of sports products and activities and the increasing monetary cycle makes the sports industry more important day by day and leads many businesses in various sectors to sell their own products and services indirectly by using sports. The institutional structure and commercialization created through the professionalization of sports carried sports to a different platform.

With the increasing structure of sports and the importance of marketing obtained through sports, the corporatization of clubs, increase in the interaction with different sectors and most importantly monetary flow and the economic return of sports have brought different problems.

Such problems as incentives, match fixing, doping, violence in stadium etc. necessitate evaluation of sports in terms of education, health, tourism, finance, production, marketing, politics and culture, its systematic organization and managing it within a modern management approach and accepting quality as a philosophy of life by all stakeholders in sports.

The administrative deadlocks manifesting themselves in such forms as waste of resources, inefficiency, unstable and poor quality of service and bureaucratic domination in fulfilling the public services in Turkey stand out. Therefore, it is often emphasized that there is a need for a new structuring which will ensure the presentation of participation and services to the whole country in an optimal way in the present environment where a rapid change is experienced $[4,5]$.

The change in Provincial Directorate of Youth and Sports operating within the provincial structuring of SGM (General 
Directorate of Sports) affiliated to the Ministry of Youth and Sports, having an important place in provincial activities, offering public service and having the possibility of being effective in management and development of various sports branches through representation offices are highly important.

Social, political, cultural, economic, environmental developments and changes occurring in the society affect sports institutions and organizations positively or negatively. One of the important concepts in which change is experienced in all areas of the society is the concept of customer-focused quality. It is inevitable that the sports sector, which is composed of both production and service sectors, will be affected by this change. If all the enterprises, organizations and institutions operating within the sports sector are evaluated within the quality understanding, both customer expectations will be met and the market shares will increase, and at the same time, the quality in sports will reach a high level [6].

Providing better and high quality service by the Provincial Directorates of Youth and Sports necessitates change and points out to a need for an organization and management structure in accordance with the modern management approach.

When the sports institutions and organizations are considered as the businesses producing service in public field, it is necessary for these enterprises to adopt a valid quality management understanding in order to increase service quality and efficiency and to meet the expectations and needs of customers. In this regard, the implementation of the Six Sigma management model seems to be applicable in the field of service and especially sports service, within the institutions and organizations as a result of their activities and in the management field which offers a kind of sports service (product).

After the legal regulations to be made, Six Sigma applications must be initiated in "Provincial Directorates of Youth and Sports". Within the framework of Six Sigma understanding, it is possible to establish quality departments and create quality culture, to ensure target population satisfaction, to increase effectiveness and efficiency, to provide continuous developments and to increase the qualifications of those who will offer service in Provincial Directorates.

In the study of Gürses [7], it is stated that the support of top management is of vital importance for the successful application of Six Sigma, organizational change must be ensured with Six Sigma and it is extremely difficult to be successful without the support of top management [7].

If it is accepted that sports enterprises are basically service-producing companies, these enterprises will need to adopt a valid quality management approach in a constantly changing and evolving world order in order to increase service quality in sports, to meet customer expectations at the optimum level and to take place in the growing competition environment in the service market. In this sense, it seems possible to apply the Six Sigma management model, which will have a big share in many success stories in the manufacturing sector and will definitely be experienced by many enterprises in the increasing global market one day, especially in the service field - particularly sports service and the management field that offers a kind of sports service (product) as a result of the activities implemented within the institutions and organizations [6].

In this study, by taking into account that Six Sigma application can't be successful without the leadership and support of top management. It was attempted to determine the opinions of employees (Provincial director, departmental manager, director of youth center, chief, sports expert and sports education expert) working in Provincial Directorates of Youth and Sports in Turkey operating within the provincial structuring of SGM affiliated to the Ministry of Youth and Sports towards the applicability of Six Sigma management model in their institution.

\section{Materials and Methods}

\subsection{Population and Sampling}

The research population is composed of the employees working in Provincial Directorates of Youth and Sports and the sample is composed of randomly selected 210 employees among those actively working in these directorates.

\subsection{Data Collection Techniques}

A questionnaire was applied concerning the opinions of randomly selected 210 employees among those working in Provincial Directorates of Youth and Sports in 2014 (Provincial director, departmental manager, director of youth center, chief, sports expert and sports education expert). A total of 244 questionnaire forms were sent during the study.

During the data collection process, the questionnaire was applied to the employees of 27 provincial directorates through personal interview, e-mail and by post. Among 244 questionnaire forms sent, 210 of them which were sent back and considered to be appropriate were taken into evaluation.

\subsection{Data Collection Tools}

As the data collection tool of the research, the questionnaire used by Yücel [16] in $\mathrm{PhD}$ dissertation titled "Applicability of Six Sigma Management Model in Turkish Sports Federations" was used. The value of 0.93 was found to be the reliability coefficient of the questionnaire (Cronbach Alpha).

Before the exploratory factor analysis, Kaiser-Meyer-Olkin (KMO) and Bartlett test were applied. KMO measurement value testing the suitability of the sample for the analysis was found as 0.690 and Bartlett's Test of Sphericity Chi-Square value was ascertained to be $966.450(\mathrm{p}=.000)$. These values indicate that the data set is 
suitable for the factor analysis.

\subsection{Statistical Analysis}

The questionnaire results were analyzed with SPSS 17.0 computer program for statistical analysis. In order to determine whether the data distribute normally in establishing the difference on opinions of employees working in Provincial Directorates of Youth and Sports about the applicability of Six Sigma management model by some independent variables (age, sex, job, term of office, education etc.) and according to the homogeneity tests of variances; "unpaired $t$ test" or "Mann Whitney U test" was used in paired comparisons of variables, "Anova" or "Kruskall-Wallis" test for inter-group differences, "Dunnett's C" was used in determining the inter-group differences where variance is nonhomogeneous and "Bonferroni" test was used for homogenous variances. Interpretations were supported with tables.
Five-point rating scale of the questionnaire for healthy interpretation of data are as follows; "strongly disagree" (1.00-1.80), "disagree" (1.81-2.60), "neutral" (2.61-3.40), "agree" (3.41-4.20) "strongly agree" (4.21-5.00).

\section{Results}

In this part, the statistical analyses of the differences between the opinions of employees working in Provincial Directorates of Youth and Sports regarding the applicability of Six Sigma model by some independent variables (age, sex, education, job, term of office etc.) are evaluated and data are presented in tables.

Analyzing the findings in Table 1 carefully, it is observed that the whole factor load of the scale changes between .419 and .890 .

Table 1. Factor loads of Factors and Variables

\begin{tabular}{|c|c|c|c|c|c|c|}
\hline & \multicolumn{6}{|c|}{ Factor } \\
\hline & 1 & 2 & 3 & 4 & 5 & 6 \\
\hline Customer orientation & & & & & .741 & \\
\hline Customer orientation & & & & & .812 & \\
\hline Customer orientation & & & & & .667 & \\
\hline Customer orientation & & & & & .710 & \\
\hline Customer orientation & & & & & .680 & \\
\hline Tolerance for failure & .622 & & & & & \\
\hline Tolerance for failure & .734 & & & & & \\
\hline Tolerance for failure & .813 & & & & & \\
\hline Tolerance for failure & .765 & & & & & \\
\hline Tolerance for failure & .678 & & & & & \\
\hline Process-oriented management and continuous development & & & .655 & & & \\
\hline Process-oriented management and continuous development & & & .788 & & & \\
\hline Process-oriented management and continuous development & & & .890 & & & \\
\hline Active participation of everyone & & & & .622 & & \\
\hline Active participation of everyone & & & & .608 & & \\
\hline Active participation of everyone & & & & .670 & & \\
\hline Contribution of management & & .620 & & & & \\
\hline Contribution of management & & .604 & & & & \\
\hline Contribution of management & & .419 & & & & \\
\hline Tolerance for failure & & & & & & .594 \\
\hline Tolerance for failure & & & & & & .732 \\
\hline Tolerance for failure & & & & & & .659 \\
\hline Tolerance for failure & & & & & & .614 \\
\hline
\end{tabular}


Concerning the findings in Table 2, "ages" of the participants are as follows; $16.2 \%$ of them (34 people) are aged 51 and over, $29.0 \%$ of them (61 people) are aged between 41 and $50,34.3 \%$ of them ( 72 people) are in the age group of $31-40$ and $20.5 \%$ of them (43 people) are in the age group of $21-30$. "Sex" of $17.6 \%$ of them (37 people) are female and $82.4 \%$ of them ( 173 people) are male.

Concerning the "education" findings of the participants, $5.2 \%$ of them (11 people) are graduates of a high school or equivalent, $23.8 \%$ of them (50 people) are graduates of School of Physical Education and Sports, $15.7 \%$ of them (33 people) have an associate degree, $47.1 \%$ of them (99 people) have an undergraduate degree and $8.1 \%$ (17 people) have a graduate degree.
"In-service training" findings of the participants are as follows; $61.4 \%$ of them (129 people) said yes and $38.6 \%$ ( 81 people) said no. The distribution of "term of office" information of managers are as follows; $30.0 \%$ of them $(63$ people) have 2 years and less, $17.1 \%$ (36 people) have $3-5$ years, $14.3 \%$ ( 30 people) have $6-8$ years, $13.3 \%$ ( 28 people) have $9-11$ years and $25.3 \%$ (53 people) have 12 years and more.

Looking at the "job" distributions of managers in Table 2, $4.3 \%$ of them ( 9 people) are provincial director, $34.8 \%$ of them ( 73 people) are departmental manager, $2.9 \%$ (6 people) are director of youth center, $18.6 \%$ (39 people) are chief, $26.6 \%(56$ people) are sports education expert and $12.9 \%(27$ people) are sports expert.

Table 2. Distribution of Descriptive Data about Some Personal Traits of Employees

\begin{tabular}{|c|c|c|c|}
\hline Variables & Sub-variables & $\mathrm{f}$ & $\%$ \\
\hline \multirow[t]{5}{*}{ Age } & $21-30$ & 43 & 20.5 \\
\hline & $31-40$ & 72 & 34.3 \\
\hline & $41-50$ & 61 & 29.0 \\
\hline & 51 and over & 34 & 16.2 \\
\hline & Total & 210 & 100.0 \\
\hline \multirow[t]{3}{*}{ Sex } & Female & 37 & 17.6 \\
\hline & Male & 173 & 82.4 \\
\hline & Total & 210 & 100.0 \\
\hline \multirow[t]{7}{*}{ Education } & Primary Education & - & - \\
\hline & High School and Equivalent & 11 & 5.2 \\
\hline & School of Phy. Education and Sports & 50 & 23.8 \\
\hline & Associate Degree & 33 & 15.7 \\
\hline & Undergraduate Degree & 99 & 47.1 \\
\hline & Graduate Degree (Master/PhD) & 17 & 8.1 \\
\hline & Total & 210 & 100.0 \\
\hline \multirow[t]{7}{*}{ Job } & Provincial director & 9 & 4.3 \\
\hline & Departmental manager & 73 & 34.8 \\
\hline & Director of youth center & 6 & 2.9 \\
\hline & Chief & 39 & 18.6 \\
\hline & Sports education expert & 56 & 26.6 \\
\hline & Sports expert & 27 & 12.9 \\
\hline & Total & 210 & 100.0 \\
\hline \multirow[t]{3}{*}{ In-service training } & Yes & 129 & 61.4 \\
\hline & No & 81 & 38.6 \\
\hline & Total & 210 & 100.0 \\
\hline \multirow[t]{6}{*}{ Term of office } & 2 years and less & 63 & 30.0 \\
\hline & $3-5$ years & 36 & 17.1 \\
\hline & $6-8$ years & 30 & 14.3 \\
\hline & $9-11$ years & 28 & 13.3 \\
\hline & 12 years and more & 53 & 25.3 \\
\hline & Total & 210 & 100.0 \\
\hline
\end{tabular}


Table 3. Mean value analysis of participants' opinions regarding the sub-dimensions of the scale

\begin{tabular}{lccc}
\hline Sub-dimensions & N & Mean & S.S \\
\hline Customer orientation & 210 & 3.95 & .70 \\
\hline Tolerance for failure & 210 & 4.25 & .78 \\
\hline Process-oriented management and continuous development & 210 & 4.09 & .75 \\
\hline Active participation of everyone & 210 & 4.36 & .78 \\
\hline Contribution of management & 210 & 3.47 & 1.05 \\
\hline Tolerance for failure & 210 & 3.93 & .74 \\
\hline
\end{tabular}

Analyzing the opinions of participants, a positive approach towards the all sub-dimensions of the scale has been observed, the lowest mean is in the dimension of "Contribution of management".

Table 4. t-test Result for the Difference of Participants' Opinions by the Variable of "Sex"

\begin{tabular}{|c|c|c|c|c|c|c|c|c|c|c|}
\hline \multirow{2}{*}{ Dependent Variables } & \multirow{2}{*}{ Groups } & \multirow{2}{*}{$\mathrm{N}$} & \multirow{2}{*}{$\%$} & \multirow{2}{*}{$\overline{\mathrm{X}}$} & \multirow{2}{*}{ SS } & \multirow{2}{*}{$\mathrm{Sd}$} & \multicolumn{2}{|c|}{ Levene } & \multirow{2}{*}{$\mathrm{t}$} & \multirow{2}{*}{$\mathrm{P}$} \\
\hline & & & & & & & $\mathrm{F}$ & $\mathrm{P}$ & & \\
\hline \multirow{2}{*}{ Customer orientation } & Female & 37 & 17.6 & 4.00 & .62 & \multirow{2}{*}{208} & \multirow{2}{*}{1.676} & \multirow{2}{*}{.197} & \multirow{2}{*}{.509} & \multirow{2}{*}{.611} \\
\hline & Male & 173 & 82.4 & 4.93 & .72 & & & & & \\
\hline \multirow{2}{*}{ Tolerance for failure } & Female & 37 & 17.6 & 4.30 & .65 & \multirow{2}{*}{208} & \multirow{2}{*}{1.145} & \multirow{2}{*}{.286} & \multirow{2}{*}{.413} & \multirow{2}{*}{.680} \\
\hline & Male & 173 & 82.4 & 4.24 & .80 & & & & & \\
\hline \multirow{2}{*}{$\begin{array}{l}\text { Process-oriented management and continuous } \\
\text { development }\end{array}$} & Female & 37 & 17.6 & 4.00 & .60 & \multirow{2}{*}{208} & \multirow{2}{*}{2.772} & \multirow{2}{*}{.097} & \multirow{2}{*}{-.843} & \multirow{2}{*}{.400} \\
\hline & Male & 173 & 82.4 & 4.11 & .78 & & & & & \\
\hline \multirow{2}{*}{ Active participation of everyone } & Female & 37 & 17.6 & 4.43 & .78 & \multirow{2}{*}{208} & \multirow{2}{*}{.119} & \multirow{2}{*}{.730} & \multirow{2}{*}{.544} & \multirow{2}{*}{.587} \\
\hline & Male & 173 & 82.4 & 4.35 & .79 & & & & & \\
\hline \multirow{2}{*}{ Contribution of management } & Female & 37 & 17.6 & 3.46 & .92 & \multirow{2}{*}{208} & \multirow{2}{*}{2.683} & 103 & -069 & 945 \\
\hline & Male & 173 & 82.4 & 3.48 & 1.08 & & & .103 & -.069 & .945 \\
\hline To & Female & 37 & 17.6 & 3.93 & .64 & 208 & 167 & 683 & 683 & 989 \\
\hline Iolerance & Male & 173 & 82.4 & 3.93 & .76 & & & .005 & .005 & \\
\hline
\end{tabular}

It has been determined in Table 4 that the opinions of the participants don't differ by their sex in all factors. It can be stated that all participants have a positive opinions about the quality approach.

Table 5. Mean and standard deviation values of participants about the scale

\begin{tabular}{|c|c|c|c|}
\hline Variables & $\mathrm{N}$ & Mean & Ss \\
\hline \multicolumn{4}{|l|}{ CUSTOMER ORIENTATION } \\
\hline Satisfaction of target population (athlete and public) is the first objective. & 210 & 4.25 & .96 \\
\hline Performance measurements should be initiated with target population. & 210 & 4.14 & .88 \\
\hline Target population is important in sports services. & 210 & 4.20 & .97 \\
\hline Expectations of target population are well-determined. & 210 & 3.73 & 1.06 \\
\hline Satisfaction level of target population is high. & 210 & 3.41 & 1.02 \\
\hline \multicolumn{4}{|l|}{ TOLERANCE FOR FAILURE } \\
\hline Tolerance for failure is necessary. & 210 & 4.16 & .94 \\
\hline Statistics should be used for data collection and analysis. & 210 & 4.27 & .92 \\
\hline Reliability of information is important for data collection. & 210 & 4.42 & .93 \\
\hline It should be clarified beforehand which measures will be the key point when evaluating work performance. & 210 & 4.24 & .83 \\
\hline Data and analysis in a way to identify variables in processes and optimize results should be applied. & 210 & 4.16 & .79 \\
\hline \multicolumn{4}{|l|}{ PROCESS-ORIENTED MANAGEMENT AND CONTINOUS DEVELOPMENT } \\
\hline The process before the point where the error occurred must be investigated through process focusing and improvement. & 210 & 4.17 & .89 \\
\hline Problems must be seen and resolved without an incident. & 210 & 4.27 & .92 \\
\hline We don't want to be reactive. & 210 & 3.84 & .93 \\
\hline
\end{tabular}




\begin{tabular}{|c|c|c|c|}
\hline ACTIVE PARTICIPATION OF EVERYONE & & & \\
\hline Collaboration is important and all employees should be responsible for quality. & 210 & 4.24 & .96 \\
\hline Everyone has a duty within the organization to improve quality. & 210 & 4.37 & .85 \\
\hline Miscommunication or conflict means great loss for the organization. & 210 & 4.49 & .85 \\
\hline \multicolumn{4}{|l|}{ CONTRIBUTION OF MANAGEMENT } \\
\hline Managers are seen by employees as family elder. & 210 & 3.38 & 1.18 \\
\hline Employees are seen as family members by managers. & 210 & 3.44 & 1.20 \\
\hline Emphasis is laid on the chain of command. & 210 & 3.60 & 1.17 \\
\hline \multicolumn{4}{|l|}{ TOLERANCE FOR FAILURE } \\
\hline It should be tolerant against failure when necessary. & 210 & 3.82 & 1.03 \\
\hline All employees in the institution should be ensured to take risk in their journey to perfection. & 210 & 3.95 & .89 \\
\hline The person who is afraid of taking a risk makes a mistake and cannot capture perfection. & 210 & 3.92 & 1.06 \\
\hline The ultimate goal is to capture perfection. & 210 & 4.01 & 1.00 \\
\hline
\end{tabular}

When the participant's opinions regarding the Six Sigma management model are examined, the item "Satisfaction level of target population is high" in the sub-dimension of Customer orientation is positive but it was found to be lower than other items $(\bar{X}=3.41)$. On the other hand, the item of "Managers are seen by employees as family elder" in the sub-dimension of "Contribution of management" $(\overline{\mathrm{X}}=3.38)$ was expressed as "neutral". The item of "Employees are seen as family members by managers" is positive as $(\overline{\mathrm{X}}=3.44)$ and the item of "Emphasis is laid on the chain of command" is positive as $(\overline{\mathrm{X}}=3.60)$ at low level though. It is important to take the full support of management in the Six Sigma management approach.

Investigating the items about the sub-dimension of "Tolerance for failure", they are seen to be positive but state that some hesitations are experienced in terms of the participants in order to get the quality. It should be remembered that the ultimate goal is to achieve quality on the road to success and effort should be made on the path to perfection without fear of taking risks.

Table 6. t-test Result of the Participants' Opinions by the Variable of "In-service Training"

\begin{tabular}{|c|c|c|c|c|c|c|c|c|c|c|}
\hline \multirow{2}{*}{ Dependent Variables } & \multirow{2}{*}{ Groups } & \multirow{2}{*}{$\mathrm{N}$} & \multirow{2}{*}{$\%$} & \multirow{2}{*}{$\bar{X}$} & \multirow{2}{*}{ SS } & \multirow{2}{*}{$\mathrm{Sd}$} & \multicolumn{2}{|c|}{ Levene } & \multirow{2}{*}{$\mathrm{t}$} & \multirow{2}{*}{$\mathrm{p}$} \\
\hline & & & & & & & $\mathrm{F}$ & $P$ & & \\
\hline \multirow{2}{*}{ Customer orientation } & Yes & 129 & 61.4 & 3.96 & .69 & \multirow{2}{*}{208} & \multirow{2}{*}{.067} & \multirow{2}{*}{.796} & \multirow{2}{*}{-.266} & \multirow{2}{*}{.791} \\
\hline & No & 81 & 38.6 & 3.94 & .72 & & & & & \\
\hline \multirow{2}{*}{ Data-based Management } & Yes & 129 & 61.4 & 4.36 & .66 & \multirow{2}{*}{208} & \multirow{2}{*}{.029} & \multirow{2}{*}{.865} & \multirow{2}{*}{-1.598} & \multirow{2}{*}{.112} \\
\hline & No & 81 & 38.6 & 4.18 & .84 & & & & & \\
\hline \multirow{2}{*}{$\begin{array}{l}\text { Process-oriented management and continuous } \\
\text { development }\end{array}$} & Yes & 129 & 61.4 & 4.19 & .67 & \multirow{2}{*}{208} & \multirow{2}{*}{.001} & \multirow{2}{*}{.981} & \multirow{2}{*}{-1.558} & \multirow{2}{*}{.121} \\
\hline & No & 81 & 38.6 & 4.03 & .79 & & & & & \\
\hline \multirow{2}{*}{ Active participation of everyone } & Yes & 129 & 61.4 & 4.48 & .65 & \multirow{2}{*}{208} & \multirow{2}{*}{1.866} & \multirow{2}{*}{.173} & \multirow{2}{*}{-1.714} & \multirow{2}{*}{.088} \\
\hline & No & 81 & 38.6 & 4.29 & .85 & & & & & \\
\hline \multirow{2}{*}{ Contribution of management } & Yes & 129 & 61.4 & 3.48 & 1.05 & \multirow{2}{*}{208} & \multirow{2}{*}{.124} & 725 & 068 & 046 \\
\hline & No & 81 & 38.6 & 3.47 & 1.06 & & & $.12 J$ & .000 & .940 \\
\hline Tolerance for failure & Yes & 129 & 61.4 & 4.02 & .70 & 208 & 180 & 665 & 48 & 140 \\
\hline 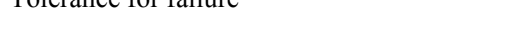 & No & 81 & 38.6 & 3.87 & .76 & 200 & .109 & .000 & -1.440 & .147 \\
\hline
\end{tabular}

In Table 6, the opinions of managers were analyzed by the variable of "In-service training" and a significant difference couldn't be found ( $p>0.05$ ).

As a result of the comparison of mean scores of answers given by the participants to the relevant items with the in-service training, it has been observed that the mean scores of the answers given by the managers receiving in-service training to the relevant items are slightly higher than the mean scores of the managers not receiving in-service training. 
In Table 7, the opinions of managers were evaluated by the variable of "term of office" and no significant difference was found ( $\mathrm{p}>0.05)$.

Table 7. One-way Analysis of Variance (Anova) Results of the Opinions of Managers by the Variable of "Term of office"

\begin{tabular}{|c|c|c|c|c|c|c|c|c|c|c|c|c|c|c|}
\hline \multirow{2}{*}{ Dependent Variables } & \multirow{2}{*}{ Groups } & \multirow{2}{*}{$\mathrm{N}$} & \multirow{2}{*}{$\%$} & \multirow{2}{*}{$\overline{\mathrm{X}}$} & \multirow{2}{*}{ SS } & \multirow{2}{*}{$\mathrm{VK}$} & \multirow{2}{*}{ KT } & \multirow{2}{*}{$\mathrm{Sd}$} & \multirow{2}{*}{ KO } & \multicolumn{2}{|c|}{ Levene } & \multirow{2}{*}{$\mathrm{F}$} & \multirow{2}{*}{$\mathrm{P}$} & \multirow{2}{*}{ Signf. Difference } \\
\hline & & & & & & & & & & $\mathrm{F}$ & $\mathrm{p}$ & & & \\
\hline \multirow{6}{*}{ Customer orientation } & $2 \leq$ years & 63 & 30.0 & 3.93 & .66 & Jnter-oroun & 0730 & 4 & 183 & \multirow{6}{*}{.755} & \multirow{6}{*}{.556} & \multirow{6}{*}{.358} & \multirow{6}{*}{.838} & \multirow{6}{*}{-} \\
\hline & $3-5$ years & 36 & 17.1 & 3.99 & .75 & Inter-group & 0.130 & 4 & .183 & & & & & \\
\hline & 6-8 years & 30 & 14.3 & 4.07 & .55 & & & & & & & & & \\
\hline & 9-11 years & 28 & 13.3 & 3.89 & .66 & Intra-group & 104.574 & 205 & .510 & & & & & \\
\hline & $12 \geq$ years & 53 & 25.3 & 3.90 & .83 & & & & & & & & & \\
\hline & Total & 210 & 100.0 & 3.95 & .70 & Total & 105.305 & 209 & & & & & & \\
\hline \multirow{6}{*}{ Data-based Management } & $2 \leq$ years & 63 & 30.0 & 4.31 & .73 & \multirow{2}{*}{ Inter-group } & \multirow{2}{*}{.769} & 4 & & & & & & \\
\hline & $3-5$ years & 36 & 17.1 & 4.26 & .88 & & & 4 & .192 & & & & & \\
\hline & $6-8$ years & 30 & 14.3 & 4.27 & .59 & & & & & & & & & \\
\hline & 9-11 years & 28 & 13.3 & 4.28 & .56 & Intra-group & 127.612 & 205 & .622 & 687 & .602 & .309 & .872 & - \\
\hline & $12 \geq$ years & 53 & 25.3 & 4.15 & .95 & & & & & & & & & \\
\hline & Total & 210 & 100.0 & 4.25 & .78 & Total & 128.381 & 209 & & & & & & \\
\hline & $2 \leq$ years & 63 & 30.0 & 4.13 & .69 & & & 4 & 117 & & & & & \\
\hline & $3-5$ years & 36 & 17.1 & 4.03 & .84 & Inter-group & .469 & 4 & .117 & & & & & \\
\hline & 6-8 years & 30 & 14.3 & 4.02 & .68 & & & & & & & & & \\
\hline Process-oriented management and continuous development & $9-11$ years & 28 & 13.3 & 4.15 & .51 & Intra-group & 119.182 & 205 & .581 & 2.119 & .734 & .202 & .937 & - \\
\hline & $12 \geq$ years & 53 & 25.3 & 4.10 & .90 & & & & & & & & & \\
\hline & Total & 210 & 100.0 & 4.09 & .75 & Total & 119.651 & 209 & & & & & & \\
\hline & $2 \leq$ years & 63 & 30.0 & 4.37 & .77 & & & & & & & & & \\
\hline & 3-5 years & 36 & 17.1 & 4.34 & .93 & Inter-group & .583 & 4 & .146 & & & & & \\
\hline & 6-8 years & 30 & 14.3 & 4.43 & .60 & & & & & & & & & \\
\hline Active participation of everyone & $9-11$ years & 28 & 13.3 & 4.45 & .49 & Intra-group & 129.828 & 205 & .633 & .803 & .524 & .230 & .921 & - \\
\hline & $12 \geq$ years & 53 & 25.3 & 4.30 & .92 & & & & & & & & & \\
\hline & Total & 210 & 100.0 & 4.36 & .78 & Total & 130.411 & 209 & & & & & & \\
\hline & $2 \leq$ years & 63 & 30.0 & 3.31 & 1.15 & & & & & & & & & \\
\hline & 3-5 years & 36 & 17.1 & 3.62 & 1.04 & Inter-group & 3.112 & 4 & .778 & & & & & \\
\hline & 6-8 years & 30 & 14.3 & 3.43 & .88 & & & & & & & & & \\
\hline Contribution of management & 9-11 years & 28 & 13.3 & 3.60 & 1.05 & Intra-group & 230.410 & 205 & 1.124 & .845 & .498 & .692 & .598 & - \\
\hline & $12 \geq$ years & 53 & 25.3 & 3.52 & 1.04 & & & & & & & & & \\
\hline & Total & 210 & 100.0 & 3.47 & 1.05 & Total & 233.522 & 209 & & & & & & \\
\hline & $2 \leq$ years & 63 & 30.0 & 3.98 & .72 & & & & & & & & & \\
\hline & 3-5 years & 36 & 17.1 & 3.89 & .79 & Inter-group & 427 & 4 & .107 & & & & & \\
\hline Tolerance for failure & 6-8 years & 30 & 14.3 & 3.93 & .67 & & & & & & & & & \\
\hline Tolerance for failure & 9-11 years & 28 & 13.3 & 3.97 & .70 & Intra-group & 115.696 & 205 & .564 & .285 & .887 & .189 & .944 & - \\
\hline & $12 \geq$ years & 53 & 25.3 & 3.87 & .80 & & & & & & & & & \\
\hline & Total & 210 & 100.0 & 3.93 & .74 & Total & 116.124 & 209 & & & & & & \\
\hline
\end{tabular}


In Table 8, the opinions of managers were analyzed by the variable of "age" and no significant difference was found ( $\mathrm{p}>0.05)$.

Table 8. One-way Analysis of Variance (Anova) Results of the Opinions of Managers by the Variable of Age

\begin{tabular}{|c|c|c|c|c|c|c|c|c|c|c|c|c|c|c|}
\hline \multirow{2}{*}{ Dependent Variables } & \multirow{2}{*}{ Groups } & \multirow{2}{*}{$\mathrm{N}$} & \multirow{2}{*}{$\%$} & \multirow{2}{*}{$\bar{X}$} & \multirow{2}{*}{ SS } & \multirow{2}{*}{ VK } & \multirow{2}{*}{ KT } & \multirow{2}{*}{$\mathrm{Sd}$} & \multirow{2}{*}{$\mathrm{KO}$} & \multicolumn{2}{|c|}{ Levene } & \multirow{2}{*}{$\mathrm{F}$} & \multirow{2}{*}{$\mathrm{P}$} & \multirow{2}{*}{ Signf. Difference } \\
\hline & & & & & & & & & & $\mathrm{F}$ & $\mathrm{p}$ & & & \\
\hline \multirow{5}{*}{ Customer orientation } & $21-30$ & 43 & 20.5 & 3.95 & .65 & \multirow{2}{*}{ Inter-group } & \multirow{2}{*}{.113} & \multirow{2}{*}{3} & \multirow{2}{*}{.038} & \multirow{5}{*}{1.079} & \multirow{5}{*}{.359} & \multirow{5}{*}{.074} & \multirow{5}{*}{.974} & \\
\hline & $31-40$ & 72 & 34.3 & 3.93 & .80 & & & & & & & & & \\
\hline & $41-50$ & 61 & 29.1 & 3.98 & .72 & & 105192 & 206 & 511 & & & & & \\
\hline & $51+$ & 34 & 16.1 & 3.92 & .54 & Intra-group & 105.192 & 200 & .511 & & & & & \\
\hline & Total & 210 & 100.0 & 3.95 & .70 & Total & 105.305 & 209 & & & & & & \\
\hline \multirow{5}{*}{ Data-based Management } & $21-30$ & 43 & 20.5 & 4.36 & .73 & \multirow{2}{*}{ Inter-group } & \multirow{2}{*}{1.010} & 3 & 337 & & & & & \\
\hline & $31-40$ & 72 & 34.3 & 4.18 & .89 & & & 3 & .331 & & & & & \\
\hline & $41-50$ & 61 & 29.1 & 4.23 & .80 & & 127372 & 206 & 618 & 863 & 461 & 544 & .653 & \\
\hline & $51+$ & 34 & 16.1 & 4.29 & .51 & Intra-group & $127.3 / 2$ & 206 & .618 & & & & & \\
\hline & Total & 210 & 100.0 & 4.25 & .78 & Total & 128.381 & 209 & & & & & & \\
\hline & $21-30$ & 43 & 20.5 & 4.17 & .74 & & & & & & & & & \\
\hline & $31-40$ & 72 & 34.3 & 3.97 & .88 & Inter-group & 2.201 & 3 & .734 & & & & & \\
\hline Process-oriented management and continuous development & $41-50$ & 61 & 29.1 & 4.09 & .83 & Intro & 117450 & 206 & 570 & 756 & 520 & 1287 & 280 & \\
\hline & $51+$ & 34 & 16.1 & 4.25 & .55 & 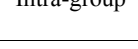 & 111.400 & 200 & .570 & & & & & \\
\hline & Total & 210 & 100.0 & 4.09 & .78 & Total & 119.651 & 209 & & & & & & \\
\hline & $21-30$ & 43 & 20.5 & 4.40 & .74 & Inter-oroun & 247 & 3 & 082 & & & & & \\
\hline & $31-40$ & 72 & 34.3 & 4.33 & .88 & miner-group & . 241 & 3 & .002 & & & & & \\
\hline Active participation of everyone & $41-50$ & 61 & 29.1 & 4.35 & .83 & & & & 632 & .430 & .732 & .130 & .942 & \\
\hline & $51+$ & 34 & 16.1 & 4.42 & .55 & Intra-group & 130.164 & 206 & .632 & & & & & \\
\hline & Total & 210 & 100.0 & 4.36 & .78 & Total & 130.411 & 209 & & & & & & \\
\hline & $21-30$ & 43 & 20.5 & 3.34 & 1.15 & Inter-aroun & 2203 & 3 & 734 & & & & & \\
\hline & $31-40$ & 72 & 34.3 & 3.44 & 1.06 & inter-group & 2.203 & 3 & .134 & & & & & \\
\hline Contribution of management & $41-50$ & 61 & 29.1 & 3.62 & .97 & Intro- & 231318 & 206 & 1123 & .687 & .561 & .654 & .581 & \\
\hline & $51+$ & 34 & 16.1 & 3.44 & 1.06 & intra-group & 251.510 & 200 & 1.120 & & & & & \\
\hline & Total & 210 & 100.0 & 3.47 & 1.05 & Total & 233.522 & 209 & & & & & & \\
\hline & $21-30$ & 43 & 20.5 & 4.06 & .70 & Inter-groun & 1077 & 3 & 359 & & & & & \\
\hline & $31-40$ & 72 & 34.3 & 3.92 & .84 & 117ter-givup & 1.011 & & 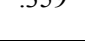 & & & & & \\
\hline Tolerance for failure & $41-50$ & 61 & 29.1 & 3.88 & .66 & Intra-oroun & 115047 & 206 & 558 & .630 & .597 & .643 & .588 & \\
\hline & $51+$ & 34 & 16.1 & 3.85 & .72 & intra-group & $115.04 /$ & 200 & .508 & & & & & \\
\hline & Total & 210 & 100.0 & 3.93 & .74 & Total & 116.124 & 209 & & & & & & \\
\hline
\end{tabular}


In Table 9, the opinions of managers were analyzed by the variable of "education" and no significant difference was found ( $\mathrm{p}>0.05$ ).

Table 9. One-way Analysis of Variance (Anova) Results of the Opinions of Managers by the Variable of "Education"

\begin{tabular}{|c|c|c|c|c|c|c|c|c|c|c|c|c|c|c|}
\hline \multirow{2}{*}{ Dependent Variables } & \multirow{2}{*}{ Groups } & \multirow{2}{*}{$\mathrm{N}$} & \multirow{2}{*}{$\%$} & \multirow{2}{*}{$\bar{X}$} & \multirow{2}{*}{ SS } & \multirow{2}{*}{ VK } & \multirow{2}{*}{ KT } & \multirow{2}{*}{$\mathrm{Sd}$} & \multirow{2}{*}{$\mathrm{KO}$} & \multicolumn{2}{|c|}{ Levene } & \multirow{2}{*}{$\mathrm{F}$} & \multirow{2}{*}{$\mathrm{p}$} & \multirow{2}{*}{$\begin{array}{c}\text { Signf. } \\
\text { Difference }\end{array}$} \\
\hline & & & & & & & & & & $\mathrm{F}$ & $\mathrm{p}$ & & & \\
\hline \multirow{6}{*}{ Customer orientation } & $\begin{array}{l}\text { High School and } \\
\text { Equivalent }\end{array}$ & 11 & 5.2 & 3.56 & .82 & \multirow[t]{2}{*}{ Inter-group } & \multirow[t]{2}{*}{4.009} & \multirow[t]{2}{*}{4} & \multirow[t]{2}{*}{1.002} & \multirow{6}{*}{.650} & \multirow{6}{*}{.628} & \multirow{6}{*}{2.028} & \multirow{6}{*}{.092} & \\
\hline & B.E.S.Y.O. & 50 & 23.9 & 4.02 & .72 & & & & & & & & & \\
\hline & Associate Deg. & 33 & 15.7 & 4.08 & .57 & \multirow{2}{*}{ Intra-group } & \multirow{2}{*}{101.296} & \multirow{2}{*}{205} & \multirow{2}{*}{.494} & & & & & \\
\hline & Undergraduate & 99 & 47.1 & 3.87 & .70 & & & & & & & & & \\
\hline & Graduate & 17 & 8.1 & 4.17 & .74 & Totol & 105305 & 200 & & & & & & \\
\hline & Total & 210 & 100.0 & 3.95 & .70 & Iotal & 105.305 & 209 & & & & & & \\
\hline & $\begin{array}{l}\text { High School and } \\
\text { Equivalent }\end{array}$ & 11 & 5.2 & 4.29 & .35 & Inter-group & 3.422 & 4 & .856 & & & & & \\
\hline & B.E.S.Y.O. & 50 & 23.9 & 4.38 & .83 & & & & & & & & & \\
\hline Data-based Management & Associate Deg. & 33 & 15.7 & 4.29 & .60 & & 124050 & 205 & 610 & .392 & .814 & 1.404 & .234 & \\
\hline & Undergraduate & 99 & 47.1 & 4.13 & .81 & Intra-group & 124.959 & 205 & .610 & & & & & \\
\hline & Graduate & 17 & 8.1 & 4.50 & .87 & & & & & & & & & \\
\hline & Total & 210 & 100.0 & 4.25 & .78 & Total & 128.381 & 209 & & & & & & \\
\hline & $\begin{array}{l}\text { High School and } \\
\text { Equivalent }\end{array}$ & 11 & 5.2 & 4.03 & .37 & Inter-group & 3.838 & 4 & .960 & & & & & \\
\hline & B.E.S.Y.O. & 50 & 23.9 & 4.20 & .71 & & & & & & & & & \\
\hline Process-oriented management and continuous & Associate Deg. & 33 & 15.7 & 4.14 & .57 & Intro or & 115812 & 205 & 565 & .742 & .564 & 1.698 & .152 & \\
\hline & Undergraduate & 99 & 47.1 & 3.97 & .85 & Intra-group & 115.813 & 200 & .563 & & & & & \\
\hline & Graduate & 17 & 8.1 & 4.41 & .70 & $T$ & $110<5$ & 200 & & & & & & \\
\hline & Total & 210 & 100.0 & 4.09 & .75 & lotal & 119.631 & 209 & & & & & & \\
\hline & $\begin{array}{l}\text { High School and } \\
\text { Equivalent }\end{array}$ & 11 & 5.2 & 4.18 & .70 & Inter-group & 2.539 & 4 & .635 & & & & & \\
\hline & B.E.S.Y.O. & 50 & 23.9 & 4.42 & .81 & & & & & & & & & \\
\hline Active participation of everyone & Associate Deg. & 33 & 15.7 & 4.50 & .52 & Intro & 127872 & 205 & 624 & .793 & .531 & 1.018 & .399 & \\
\hline & Undergraduate & 99 & 47.1 & 4.28 & .83 & Intra-group & $12 / .8 / 2$ & 205 & .624 & & & & & \\
\hline & Graduate & 17 & 8.1 & 4.56 & .90 & Total & 130411 & 200 & & & & & & \\
\hline & Total & 210 & 100.0 & 4.36 & .78 & 10tal & 150.411 & 209 & & & & & & \\
\hline & $\begin{array}{l}\text { High School and } \\
\text { Equivalent }\end{array}$ & 11 & 5.2 & 3.42 & .95 & Inter-group & 3.650 & 4 & .912 & & & & & \\
\hline Contribution of management & B.E.S.Y.O. & 50 & 23.9 & 3.35 & 1.08 & & & & & .411 & .800 & .814 & .518 & \\
\hline & Associate Deg. & 33 & 15.7 & 3.68 & 1.01 & Intro- & 220872 & 205 & 1121 & & & & & \\
\hline & Undergraduate & 99 & 47.1 & 3.43 & 1.09 & Intra-group & $229.8 / 2$ & 205 & 1.121 & & & & & \\
\hline
\end{tabular}




\begin{tabular}{|c|c|c|c|c|c|c|c|c|c|c|c|c|c|}
\hline & Graduate & 17 & 8.1 & 3.74 & .91 & \multirow{2}{*}{ Total } & \multirow{2}{*}{233.522} & \multirow{2}{*}{209} & & & & & \\
\hline & Total & 210 & 100.0 & 3.47 & 1.05 & & & & & & & & \\
\hline \multirow{6}{*}{ Tolerance for failure } & $\begin{array}{l}\text { High School and } \\
\text { Equivalent }\end{array}$ & 11 & 5.2 & 3.84 & .74 & \multirow[t]{2}{*}{ Inter-group } & \multirow[t]{2}{*}{.571} & \multirow[t]{2}{*}{4} & \multirow[t]{2}{*}{.143} & \multirow{6}{*}{.206} & \multirow{6}{*}{.935} & \multirow{6}{*}{.253} & \multirow{6}{*}{.907} \\
\hline & B.E.S.Y.O. & 50 & 23.9 & 4.01 & .80 & & & & & & & & \\
\hline & Associate Deg. & 33 & 15.7 & 3.96 & .67 & \multirow{2}{*}{ Intra-group } & \multirow{2}{*}{115.553} & \multirow{2}{*}{205} & \multirow{2}{*}{.564} & & & & \\
\hline & Undergraduate & 99 & 47.1 & 3.89 & .74 & & & & & & & & \\
\hline & Graduate & 17 & 8.1 & 3.89 & .75 & \multirow{2}{*}{ Total } & \multirow{2}{*}{116.124} & \multirow{2}{*}{209} & & & & & \\
\hline & Total & 210 & 100.0 & 3.93 & .74 & & & & & & & & \\
\hline
\end{tabular}

In Table 10, the opinions of managers were analyzed by the variable of "job" and no significant difference was observed ( $p>0.05)$.

Table 10. One-way Analysis of Variance (Anova) Results of the Opinions of Managers by the Variable of "Job"

\begin{tabular}{|c|c|c|c|c|c|c|c|c|c|c|c|c|c|c|}
\hline \multirow{2}{*}{ Dependent Variables } & \multirow{2}{*}{ Groups } & \multirow{2}{*}{$\mathrm{N}$} & \multirow{2}{*}{$\%$} & \multirow{2}{*}{$\overline{\mathrm{X}}$} & \multirow{2}{*}{ SS } & \multirow{2}{*}{ VK } & \multirow{2}{*}{ KT } & \multirow{2}{*}{$\mathrm{Sd}$} & \multirow{2}{*}{$\mathrm{KO}$} & \multicolumn{2}{|c|}{ Levene } & \multirow{2}{*}{$\mathrm{F}$} & \multirow{2}{*}{$\mathrm{p}$} & \multirow{2}{*}{$\begin{array}{c}\text { Signf. } \\
\text { Difference }\end{array}$} \\
\hline & & & & & & & & & & $\mathrm{F}$ & $\mathrm{p}$ & & & \\
\hline \multirow{7}{*}{ Customer orientation } & Provincial director & 9 & 4.3 & 4.15 & .51 & \multirow[b]{2}{*}{ Inter-group } & \multirow[b]{2}{*}{1.872} & \multirow[b]{2}{*}{5} & \multirow[b]{2}{*}{.493} & \multirow{7}{*}{1.263} & \multirow{7}{*}{.281} & \multirow{7}{*}{.738} & \multirow{7}{*}{.596} & \\
\hline & Departm. manager & 73 & $\begin{array}{c}34.8 \\
7\end{array}$ & 3.98 & .61 & & & & & & & & & \\
\hline & $\begin{array}{l}\text { Youth center } \\
\text { director }\end{array}$ & 6 & 2.8 & 4.26 & .27 & \multirow{2}{*}{ Intra-group } & \multirow{2}{*}{103.433} & \multirow{2}{*}{204} & \multirow{2}{*}{.268} & & & & & \\
\hline & Chief & 39 & 18.6 & 3.81 & .80 & & & & & & & & & \\
\hline & Sports educ. expert & 56 & 26.7 & 3.92 & .81 & \multirow{3}{*}{ Total } & \multirow{3}{*}{105.305} & \multirow{3}{*}{209} & & & & & & \\
\hline & Sports expert & 27 & 12.8 & 3.98 & .69 & & & & & & & & & \\
\hline & Total & 210 & 100.0 & 3.95 & .70 & & & & & & & & & \\
\hline \multirow{7}{*}{ Data-based Management } & Provincial director & 9 & 4.3 & 4.40 & .76 & \multirow[b]{2}{*}{ Inter-group } & & & & & & & & \\
\hline & Departm. manager & 73 & $\begin{array}{c}34.8 \\
7\end{array}$ & 4.21 & .71 & & .932 & 5 & .625 & & & & & \\
\hline & $\begin{array}{l}\text { Youth center } \\
\text { director }\end{array}$ & 6 & 2.8 & 4.36 & .49 & Intra-group & 127.449 & 204 & .191 & & & & & \\
\hline & Chief & 39 & 18.6 & 4.18 & .80 & & & & & .408 & .843 & .298 & .913 & \\
\hline & Sports educ. expert & 56 & 26.7 & 4.25 & .91 & & & & & & & & & \\
\hline & Sports expert & 27 & 12.8 & 4.37 & .75 & Total & 128.381 & 209 & & & & & & \\
\hline & Total & 210 & 100.0 & 4.25 & .78 & & & & & & & & & \\
\hline & Provincial director & 9 & 4.3 & 4.07 & .92 & & & & & & & & & \\
\hline $\begin{array}{l}\text { Process-oriented management and continuous } \\
\text { development }\end{array}$ & Departm. manager & 73 & $\begin{array}{c}34.8 \\
7 \\
\end{array}$ & 4.13 & .70 & Inter-group & .559 & 5 & .311 & .467 & .801 & .192 & .965 & \\
\hline & Youth center & 6 & 2.8 & 4.22 & .65 & Intra-group & 119.091 & 204 & .209 & & & & & \\
\hline
\end{tabular}




\begin{tabular}{|c|c|c|c|c|c|c|c|c|c|c|c|c|c|}
\hline & \multicolumn{5}{|l|}{ director } & & & & & & & & \\
\hline & Chief & 39 & 18.6 & 4.00 & .78 & & & & & & & & \\
\hline & Sports educ. expert & 56 & 26.7 & 4.10 & .85 & \multirow{3}{*}{ Total } & \multirow{3}{*}{119.651} & \multirow{3}{*}{209} & & & & & \\
\hline & Sports expert & 27 & 12.8 & 4.06 & .64 & & & & & & & & \\
\hline & Total & 210 & 100.0 & 4.09 & .75 & & & & & & & & \\
\hline \multirow{7}{*}{ Active participation of everyone } & Provincial director & 9 & 4.3 & 4.62 & .65 & \multirow[b]{2}{*}{ Inter-group } & \multirow[b]{2}{*}{1.202} & \multirow[b]{2}{*}{5} & \multirow[b]{2}{*}{.824} & \multirow{7}{*}{.877} & \multirow{7}{*}{.497} & \multirow{7}{*}{.379} & \multirow{7}{*}{.862} \\
\hline & Departm. manager & 73 & $\begin{array}{c}34.8 \\
7 \\
\end{array}$ & 4.36 & .76 & & & & & & & & \\
\hline & $\begin{array}{l}\text { Youth center } \\
\text { director }\end{array}$ & 6 & 2.8 & 4.33 & .51 & \multirow{2}{*}{ Intra-group } & \multirow{2}{*}{129.209} & \multirow{2}{*}{204} & \multirow{2}{*}{.249} & & & & \\
\hline & Chief & 39 & 18.6 & 4.41 & .76 & & & & & & & & \\
\hline & Sports educ. expert & 56 & 26.7 & 4.27 & .95 & \multirow{3}{*}{ Total } & \multirow{3}{*}{130.411} & \multirow{3}{*}{209} & & & & & \\
\hline & Sports expert & 27 & 12.8 & 4.41 & .63 & & & & & & & & \\
\hline & Total & 210 & 100.0 & 4.36 & .78 & & & & & & & & \\
\hline \multirow{7}{*}{ Contribution of management } & Provincial director & 9 & 4.3 & 3.96 & .67 & \multirow[b]{2}{*}{ Inter-group } & \multirow[b]{2}{*}{5.281} & \multirow[b]{2}{*}{5} & \multirow[b]{2}{*}{2.068} & \multirow{7}{*}{2.923} & \multirow{7}{*}{1.715} & \multirow{7}{*}{.944} & \multirow{7}{*}{.453} \\
\hline & Departm. manager & 73 & $\begin{array}{c}34.8 \\
7 \\
\end{array}$ & 3.38 & 1.02 & & & & & & & & \\
\hline & $\begin{array}{l}\text { Youth center } \\
\text { director }\end{array}$ & 6 & 2.8 & 4.11 & .86 & Intra-group & 228.240 & 204 & .523 & & & & \\
\hline & Chief & 39 & 18.6 & 3.50 & 1.11 & & & & & & & & \\
\hline & Sports educ. expert & 56 & 26.7 & 3.42 & 1.16 & & & & & & & & \\
\hline & Sports expert & 27 & 12.8 & 3.49 & .94 & Total & 233.522 & 209 & & & & & \\
\hline & Total & 210 & 100.0 & 3.47 & 1.05 & & & & & & & & \\
\hline & Provincial director & 9 & 4.3 & 4.27 & .52 & & & & & & & & \\
\hline & Departm. manager & 73 & $\begin{array}{c}34.8 \\
7 \\
\end{array}$ & 3.83 & .69 & Inter-group & 2.274 & 5 & .249 & & & & \\
\hline & $\begin{array}{l}\text { Youth center } \\
\text { director }\end{array}$ & 6 & 2.8 & 4.16 & .75 & Intra-group & 113.850 & 204 & .251 & & & & \\
\hline Tolerance for failure & Chief & 39 & 18.6 & 3.99 & .81 & & & & & .286 & .920 & .815 & .540 \\
\hline & Sports educ. expert & 56 & 26.7 & 3.91 & .79 & & & & & & & & \\
\hline & Sports expert & 27 & 12.8 & 3.96 & .72 & Total & 116.124 & 209 & & & & & \\
\hline & Total & 210 & 100.0 & 3.93 & .74 & & & & & & & & \\
\hline
\end{tabular}




\section{Discussion and Conclusions}

The opinions of those working in Provincial Directorates of Youth and Sports regarding the applicability of Six Sigma management model were ascertained in this research. In this part of the study, the analysis of data obtained and the results are interpreted.

The mean of the answers of managers given to the sub-dimensions of the principle "Customer orientation" is observed to be at high level $(\overline{\mathrm{X}}=3.95)$ (Table 5). In the study of Yücel [16], it has been determined that the average related to this principle is also high $(\overline{\mathrm{X}}=4.00)$. In the study of Kağnıcioğlu [10], customer orientation is expressed as creating new systems, methods and ways by doing the right job at the right time at once and trying to offer the best service to the customer [10]. High averages of managers who have participated in our research regarding the principle of "Customer orientation" is important in that it shows they have correctly perceived the sub-dimensions of this principle and they have adopted this principle. It has also been determined that mean answers given by the managers to the item "Satisfaction level of target population is high" being the sub-dimension of "Customer orientation" principle is positive $(\overline{\mathrm{X}}=3.41)$ but not at the desired level. Mean responses given to the statement "Performance measurements should be initiated with target population" ( $\overline{\mathrm{X}}=4.14)$ was found to be high. It is possible to see the similar result $(\bar{X}=4.12)$ in the study of Yücel [16]. In the study of Pande et al. [12], it is stated that customer orientation has the priority in Six Sigma and performance measurements should start with the customer. It can be stated in our research that the opinions of managers regarding the principle of "Customer orientation" support the applicability of Six Sigma in these institutions.

It is observed in our study that the average of the answers given by managers to the sub-dimensions of the principle of "data-based management" ( $\overline{\mathrm{X}}=4.25)$ is high (Table 5). The relevant average about this dimension was also found high $(\bar{X}=4.40)$ in the study of Yücel [16].

It has also been ascertained that the mean value of responses given by participants to the statement of "Reliability of information is important for data collection" $(\overline{\mathrm{X}}=4.42)$ is high. While the average of the responses given to the statement "It should be clarified beforehand which measures will be the key point when evaluating work performance" was $(\bar{X}=4.24)$, this average was found as $(\bar{X}=4.37)$ in the study of Yücel [16]. These findings support the research.

It can be stated in our research that the opinions of participants regarding the principle of "data-based management" support the applicability of Six Sigma in Provincial Directorates. It is also possible to conclude in line with the participants' opinions that the participants are aware of the need to act based on data rather than assumptions and predictions in the decision-making process.
It is observed in our study that the average of the answers given by managers to the sub-dimensions of the principle "process-oriented management and continuous development" is $(\bar{X}=4.09)$ at high level (Table 5). This average was also found high $(\overline{\mathrm{X}}=4.31)$ in the study of Yücel [15]. In the study of Tezsürücü and Tunail [14], it is emphasized that Six Sigma is a project-oriented approach and the steps requiring improvement in the process are addressed as separate projects, and improvements are made [14]. In the study of Brue and Launsby [2], it is stated that Six Sigma is actually based on the error-dependent measurement of the process. It is stated in the study of Haikonen et al. [9] that controlling both service and production process ensures an increase in customer satisfaction. It can be expressed for our study that the opinions of the participants regarding the principle "process-oriented management and continuous development" which constitutes a basis for Six Sigma support the applicability of Six Sigma in Provincial Directorates and participants exhibit a conscious approach.

It is observed in our study that the mean value of answers given by managers to the sub-dimensions of the principle "Active participation of everyone" ( $\bar{X}=4.36)$ is high (Table 5). The same average $(\bar{X}=4.36)$ was found in the study of Yücel [16]. While the average related to the item "collaboration is important and all employees should be responsible for quality" was $(\overline{\mathrm{X}}=4.24)$, a similar high value $(\bar{X}=4.40)$ was obtained in the study of Yücel [16].

It has also been determined that the average of answers given to the statement "Miscommunication or conflict means great loss for the organization" was found to be high $(\bar{X}=4.49)$. In the study of Pande et al. [13], it is stated that miscommunication among the groups that need to work together to deliver value to the customer leads to significant losses and that the Six Sigma system can create an environment and management structure to support real team work [13]. It can be uttered for our research that the participant opinions concerning the principle of "Active participation of everyone" support the applicability of Six Sigma in Provincial Directorates.

It is observed in our study that the mean value of answers given by managers to the sub-dimensions of the principle of "Contribution of management" $(\bar{X}=3.47)$ indicates the selection of "agree" (Table 5). In the study of Yücel [16], this ratio was found as $(\bar{X}=3.83)$. Gürses [7] states in his study that the support of top management is of vital importance for a successful application of Six Sigma, organizational change must be ensured with Six Sigma and it is really difficult to be successful without obtaining the support of top management [7]. The mean value of answers given by the participants to the principle of "contribution of management" was found to be lower than other principles. The average of the answers given to the statement "Managers are seen by employees as family elder" being in the sub-dimension of this principle was $\overline{\mathrm{X}}=3.38$ and the average of answers given to the statement of "Employees are seen as family members by managers" was ascertained 
as $\bar{X}=3.44$. These ratios were found as $\bar{X}=3.72$ and $\bar{X}$ $=3.79$ respectively in the study of Yücel [16]. However, the opinions of managers about the principle of "contribution of management" support the applicability of Six Sigma in Provincial Directorates in our study.

In Table 8, the opinions of managers were statistically analyzed by the variable of "age" and no significant difference was found ( $p>05)$. In the study of Demir [3], it is stated that the opinions of managers on the applicability of a quality system don't differ by the variable of age [3]. It can be expressed in line with this result that the age differences between the participants of our study don't change the perspective on the applicability of Six Sigma.

Analyzing the Table 5 revealing the opinions of managers, it is observed that no significant difference has been found in terms of the variable of "sex" ( $p>.05)$. It is stated in the study of Demir [3] that the opinions of managers don't create a significant difference by the variable of sex [3]. Expressing according to this result, sex of the managers doesn't change their perspective on Six Sigma. The opinions of male and female managers on the applicability of Six Sigma management model comply with each other.

In Table 9, the opinions of managers were statistically analyzed by the variable of "education" and no significant difference was found ( $p>.05)$. In the study of Demir [3], no significant difference was stated in terms of the variable of "education" regarding the applicability of quality [3]. According to these results, it can be said that those with graduate degree utter more positive opinions than other education groups considering the general averages. As the education level increases, there is also a positive increase in the opinions.

In Table 10, the opinions of managers were analyzed by the variable of job. In this regard, no significant difference was found $(\mathrm{p}>.05)$. According to the condition of top management's believing, desiring and providing environment and opportunities being one of the important conditions in Six Sigma applications [1], positive opinions of provincial directors, departmental managers and youth center directors ranking at the top management level are important for the applicability of Six Sigma.

The basis of the application of Six Sigma starts with the determination of target audience. Finding out what the target audience really wants and how their needs and wants change over time is of great importance in the Six Sigma application process [15]. According to the findings in our study, Provincial Directors and Youth Center Directors delivered positive opinion by the variable of "Customer orientation".

In Table 6, the opinions of managers didn't reveal any statistically significant difference by the variable of "in-service training" ( $p>05)$. Based on this variable, it is observed that managers who have received in-service training seem to give more positive responses to the questions in sub-dimensions.
$61.4 \%$ of the participants have stated that they have received in-service training in the field of management and sports. It can be stated that in-service training positively affected the perspectives on quality concerning the topics of cooperation in the institution, task sharing and quality responsibility. However, these trainings received from the institution can be stated to be insufficient.

Average opinions of managers stating that the cooperation is important in the institution and all employees should be responsible for quality was found to be high $(\overline{\mathrm{X}}=4.24)$ and the average of those believing that everyone must have a duty in order to increase quality was high $(\bar{X}=4.37)$. In the study of Gross [8], stating that the success of the enterprises on the road to Six Sigma quality level depends on creating a revolution in the cultural sense, he has emphasized that all employees' participation is inevitable [8]. This finding is in parallel with the participants' opinions in our study.

In Table 7, the opinions of managers didn't reveal any statistically significant difference by the variable of "term of office" ( $p>.05)$. In general terms, it is observed that the participants having 12 years and more term of office have low averages. It is expected that employees with long term of office approach quality management understanding more positively by exhibiting an attitude open to change and development in the style of management due to the fact that they have better knowledge about the operation and structure of the institution and they can follow in-house activities more closely. However, the findings obtained indicate that the employees with higher term of office can accept the current situation more easily.

Six Sigma aims to achieve the perfection by reducing the margin of error in institutions. The benefits of Six Sigma should be explained to the staff before the application by providing in-service training. Among the reasons why Six Sigma cannot be applied are lack of financial resources, lack of expert leadership in relevant matter, lack of in-service training and inadequacy of human resources [11]. Considering these issues, it is important to establish the necessary service units for the application of the Six Sigma model in the institutions, to provide in-service training, to receive consultancy services when necessary, and to carry out the necessary work in order to meet the costs by the relevant upper units.

As a result of the analysis of participant opinions on applicability of Six Sigma management model in Provincial Directorates, it can be concluded that the leadership of top management is of vital importance for "Six Sigma" applications. Six Sigma applications will be successful in provincial directorates in line with the positive opinions of the participants. The applicability of Six Sigma management model seems to be possible in Provincial Directorates of Youth and Sports and a basis is provided for the creation of Six Sigma management model in these institutions. 


\section{Acknowledgements}

The authors thank everyone for their participation.

\section{Conflicts of Interest}

The authors declare no conflict of interest.

\section{Funding}

This research received no external funding.

\section{REFERENCES}

[1] Anonim, (2010), Alt1 Sigma Gerçeği. Access: (http://www.kalder.org\%20/genel/\%2011ukk\%20sunumcv/ 1D \%20halit\%20kasa\%20bildiri.pdf) Access Date: 14. 05. 2010 .

[2] Brue, G, Launsby, R.G. (2003). Design for Six Sigma, London McGraw-Hill Professional, New York. p.2.

[3] Demir, İ. (2008). Spor Federasyonlarında Toplam Kalite Yönetiminin Uygulanabilirliği, Master's Thesis. Ankara: Gazi University, Institute of Health Sciences.

[4] Devecioğlu, S., Çoban B. (2003). Türkiye'de Futbol Federasyonunun Özerkliği, Gazi Bed.Eğt. ve Spor Bil. Der. Issue (VIII) 3:49-58.

[5] Doğar, Y. (1997). Türkiye'de Spor Yönetimi, Öz Akdeniz Ofset, Malatya, p: 63-95.

[6] Devecioğlu, S., Yücel, A.S. (2012). Spor Sektörü ve Altı Sigma Yönetim Modeli, SPORMETRE Beden Eğitimi ve Spor Bilimleri Dergisi, 2012, X (1) 17-24

[7] Gürses, D. (2005). İșletmelerde Kalitenin Sürekliliğinin Sağlanmasında Altı Sigma Yaklaşımı ve Bir Uygulama Örneği. (Non-thesis Master's Thesis Project), Dokuz Eylül University, Institute of Social Sciences, İzmir. p: 48-57.

[8] Gross, J.M. (2001). A Road Map to Six Sigma Quality, Quality Progress, 24-29.

[9] Haikonen, A., Savolainen, T., Jarvinen, P. (2004). Exploring Six Sigma And CI Capability Development: Preliminary Case Study Findings On Management Role, Journal of Manufacturing Technology Management, Vol.15, No. 4, p. 372

[10] Kağnicioğlu, H. (2002). Günümüzde İşletmelerin Yaşam Anahtarı: Müş̧teri Odaklılık, Ege Akademik Bakış, Issue:1, Year: 2, pp.: 78-90.

[11] Kuşçu, F.N., Karaman, M., Kuşçu Karatepe, H., Alici, H., Özcan Yüce, U., Atik, D. (2018). Six Sigma and Total Quality Management in Health Institutions, Journal of Current Researches on Health Sector, 8 (1): 126-136.

[12] Pande, P., Neuman, R., Cavanagh, R. (2000). The Six Sigma Way How GE, Motorola and Other Top Companies are
Honing Their Performance. McGraw-Hill, New York.

[13] Pande, P. S., Neuman, R. P., Cavanagh, R. R. (2003). Six Sigma Yolu. $1^{\text {st }}$ Edition. Translated by: Nafiz Güder/Güneş Tokcan, Klan Yayınları. İstanbul. pp. 9, 31, 32, 36, 37, 115-121.

[14] Tezsürücü, D., Tunail, İ. (2010). Altı Sigma Metodolojisi ve Otomotiv Sektöründe Bir Örnek Olay İncelemesi, Celal Bayar University, Sosyal Bilimler Dergisi, issue: 8 no:1.

[15] Turan, A.H., Şenkayas, H., Başaloğlu, C. (2008). Alt Sigma'nın Kobilerde Farkındalılığı, Ayırt Edici Faktörler ve Uygulama Karakteristikleri: Aydın İlinde Ampirik Bir Değerlendirme. Afyon Kocatepe University, İ.İ.B.F. Dergisi, C.X ,S II.

[16] Yücel, A.S. (2012). Türk Spor Federasyonlarında Altı Sigma Yönetim Modelinin Uygulanabilirliği, Frat University, Institutue of Health Sciences, PhD Thesis, Elazı $\breve{g}$.

*This study was presented as a verbal presentation at the 4th international congress on economy administration and market surveys held in Kocaeli on 24-25 March 2017. 